\title{
Synthesis and Some Physical-Chemical Properties of meso-Aryl- and $\beta$-Alkyl Substituted Corroles and their Metal Complexes
}

\author{
Daria V. Petrova, ${ }^{a}$ Alexandr S. Semeikin, ${ }^{\text {a@ }}{ }$ Nadezhda M. Berezina, ${ }^{a}$ \\ Mikhail B. Berezin, ${ }^{\mathrm{b}}$ and Mikhail I. Bazanov
}

Dedicated to the 90th birthday of Boris Dmitrievich Berezin

avanovo State University of Chemistry and Technology, 153000 Ivanovo, Russia

${ }^{\mathrm{b}}$ G.A. Krestov Institute of Solution Chemistry of RAS, 153045 Ivanovo, Russia

@Corresponding authorE-mail: semeikin@isuct.ru

\begin{abstract}
The synthesis of meso-aryl-and $\beta$-alkylcorroles and their metal complexes is given in the article. Electrochemical and photooxidative properties of these compounds have been studied. All synthesized corroles are characterized by the data of UV-Vis and ${ }^{1} H$ NMR spectroscopy, and mass spectrometry.
\end{abstract}

Keywords: Synthesis, corroles, metal complexes, electrochemistry, photooxidative destruction.

\section{Синтез и некоторые физико-химические свойства мезо-арил- и $\beta$-акилзамещенных корролов и их металлокомплексов}

\author{
А. В. Петрова, ${ }^{a}$ А. С. Семейкин, ${ }^{a} @$ Н. М. Березина, ${ }^{a}$ М. Б. Березин, ${ }_{1}^{\mathrm{b}}$ М. И. Базанова
}

Посвящается 90-летию со дня рождения Бориса Амитриевича Березина

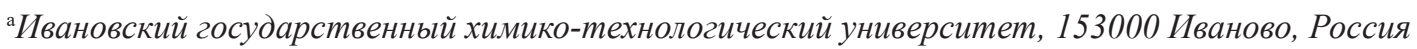

${ }^{\mathrm{b}}$ Институт химии растворов им. Г.А. Крестова, 153045 Иваново, Россия

E-mail: semeikin@isuct.ru
\end{abstract}

\begin{abstract}
В статье приведен синтез мезо-арил- и $\beta$-алкилкорролов и их металлокомплексов. Изучены электрохимические и фотоокислительныле свойства полученных соединений. Все синтезированнье корроль охарактеризовань данными масс-спектрометрии, электронной и ${ }^{1}$ Н ЯМР спектроскопии.
\end{abstract}

Ключевые слова: Синтез, корролы, металлокомплексы, электрохимия, фотоокислительная деструкция.

\section{Introduction}

Recently the interest to aromatic tetrapyrrolic analogs of porphyrins, having a distortion reaction core, has significant growth. The corroles don't have one of a methine bridge, due to the fact that the reaction center of the corroles has a distortion trapezium shape, unlike the square reaction center of the porphyrins.
Corroles possess aromatic macrocyclic conjugated system like porphyrins: their visible spectra have intensive band about $400 \mathrm{~nm}$ (Soret-band) and more weak bands in range of 500-600 nm which are similar to porphyrin's $B$ - and $Q$-bands. There is a significant shift of signals of intra-cyclic NH-protons into the strong field and that of $\beta$-protons of macrocycle into the low field in the ${ }^{1} \mathrm{H}$ NMR spectra of corroles. It says about 
presence of diamagnetic ring current and aromaticity of these compounds..$^{[1,2]}$

Coordination chemistry of corroles possesses a range of specific features, due to the presence of three protons in the interior cavity of cycle. Thus, the properties of a trianion corroles ligand greatly differ from the dianion porphyrin one. ${ }^{[1,2]}$

Corroles, as well as their metal complexes, are promising compounds for studying, because these compounds can be used as catalysts and photosensitizers. ${ }^{[2]}$ However, many of the potentially useful physicochemical properties of these compounds have not been studied yet. Thus, the aim of this work was the synthesis of meso- and $\beta$-substituted corroles and their metal complexes based, as well as the study and comparison of their electrochemical and photooxidative properties.

Owing to the position of substituents on the periphery of macrocycle, the corroles are subdivided into the meso-substituted corroles $\mathbf{1}$ and $\beta$-substituted corroles 2 . The methods of corroles synthesis enormously differ due to the position of substituents.

meso-Substituted corroles $\mathbf{1}$ are obtained by the oxidative condensation of pyrroles with aromatic aldehydes (Scheme 1).

One of the first synthesized corroles in this way is 5,10,15-triphenylcorrole, obtained by Paolesse et al. ${ }^{[3]}$ The synthetic procedure is a modified Alder's method used for the synthesis of analogous porphyrins. ${ }^{[4,5]}$ It has been determined, ${ }^{[6]}$ that the final product of this reaction highly depends on the molar ratio of precursor compounds. At 1:1 pyrrole:benzaldehyde ratio the porphyrin formation mostly occurs, the corrole is formed with the excess of pyrrole. The optimal molar pyrrole:benzaldehyde ratio for the corrole synthesis is $3: 1$, however even in this case the corresponding porphyrin is formed as a side product. The increase of the pyrrole excess is not demanded, because it leads to the increase of polymerization products. This complicates the purification of compound.

Another approach of the corrole synthesis from pyrroles and aldehydes is a modification of Lindsey's method for obtaining analogous porphyrins in mild conditions by using low boiling solvent (methylene chloride) and boron trifluoride etherate $\left(\mathrm{BF}_{3} \cdot \mathrm{OEt}_{2}\right)$ or triflouroacetic acid as a catalyst, and DDQ (2,3-dichloro-5,6-dicyanobenzoquinone-1,4) or $p$-chloranil as a cycling and oxidizing reagent for the forming of corrole 1 from intermediate bilane $3 .{ }^{[7,8]}$ A two-step modification of the method was suggested. ${ }^{\left[{ }^{[9]}\right.}$ The cardinal differences of this method are the use of a water-methanol mixture as a solvent and a small quantity of hydrochloric acid as a catalyst. The intermediate bilane $\mathbf{3}$ is extracted from water-methanol mixture by chloroform. The following oxidizing step by $p$-chloranil is carried out in this solvent.

The general method of $\beta$-alkylsubstituted corroles synthesis $\mathbf{2}$ is the radical cyclization of their line intermediate $a, c$-biladienes, usually in the form of dihydrobromides 4 (due to instability of free base), under the action of oxidizing agent ${ }^{[10]}$ (Scheme 2). The cyclization is carried out in the alcohols in the presence of base, such as an ammonia or sodium bicarbonate. ${ }^{[10-12]}$ This allows to carry out conversion of biladiene from salt into free base. The air oxygen under the illumination ${ }^{[10]}$ is an oxidizing agent, however, for this purpose, $p$-chloranil ${ }^{[12]}$ or potassium hexacyanoferrite $\mathrm{K}_{3}\left[\mathrm{Fe}(\mathrm{CN})_{6}\right]^{[11,13]}$ also can be used.

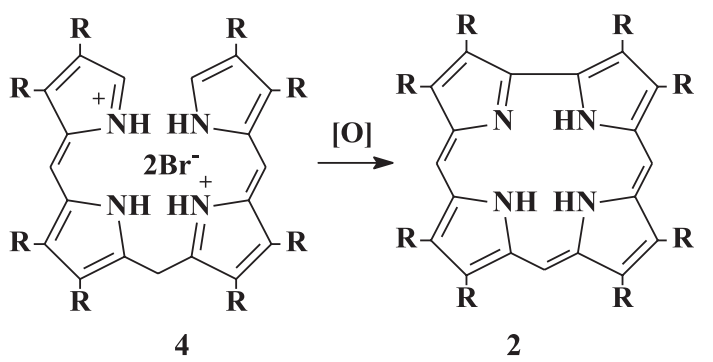

Scheme 2.

Coordination properties of the coroles have significant differences from those of porphyrins. The interior cavity of the corroles has three interior-cyclic protons. That is why in the reaction of complexation with metals they interact as trianion ligand, unlike dianion porphyrins. Although coordination properties of corroles are not studied so well as of porphyrins, a lot of information about their ability to form complexes with different groups of metals and non-metals such as boron and phosphorus has already been obtained. The metals, capable of complexation with corroles, can be conditionally subdivided into two general groups. They are transition metals $\mathrm{Ti}^{\mathrm{IV}}, \mathrm{V}^{\mathrm{IV}}, \mathrm{Ni}^{\mathrm{III}}, \mathrm{Cu}^{\mathrm{III}}, \mathrm{Ag}^{\mathrm{III}}, \mathrm{Cr}^{\mathrm{III}}, \mathrm{Mo}^{\mathrm{V}}, \mathrm{Mn}^{\mathrm{III}}$, $\mathrm{Re}^{\mathrm{V}}, \mathrm{Fe}^{\mathrm{III}}, \mathrm{Ru}^{\mathrm{III}}, \mathrm{Co}^{\mathrm{III}}, \mathrm{Rh}^{\mathrm{III}}, \mathrm{Ir}^{\mathrm{III}}$ and metals of main groups $\mathrm{Ga}^{\mathrm{III}}, \mathrm{Al}^{\mathrm{III}}, \mathrm{Ge}^{\mathrm{IV}}, \mathrm{In}^{\mathrm{III}}, \mathrm{Sn}^{\mathrm{IV}}, \mathrm{Sb}^{\mathrm{III}}$. $^{[1,2,14,15]}$

The main method of synthesis of corrole complexes $\mathbf{5}$, like porphyrin complexes, is the interaction of metal-free corroles with metal salt in suitable solvents, which dissolve both the ligand and the corresponding metal salt (Scheme 3).

Moreover, cyclization of $a, c$-biladiene in the presence metal salt is a specific method of the $\beta$-alkylcorroles 2 metal complexes synthesis. ${ }^{[16]}$ It is a more direct approach,

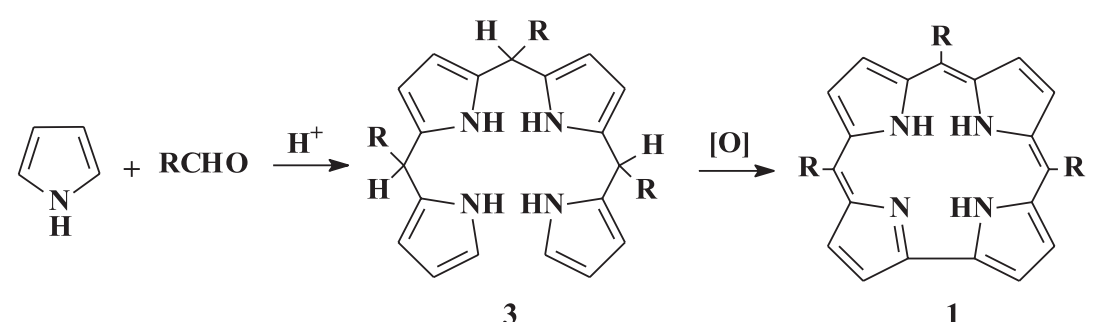

Scheme 1. 
but it isn't always applied, because some ions of metals are capable to catalyze the cyclization of linear tetrapyrroles without coordination. The product of the reaction in this case is a corresponding free base of corrole.

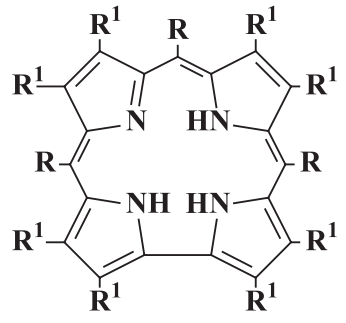

1,2

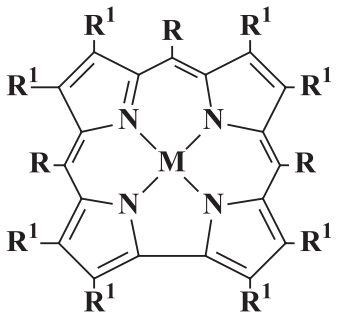

5
Scheme 3.

\section{Experimental}

Electronic absorption spectra were measured on a SPEC SSP-715 scanning spectrometer, and proton magnetic resonance spectra ( ${ }^{1} \mathrm{H}$ NMR) were recorded on a Bruker 500 spectrophotometer at the Center for Collective Use of Scientific Equipment "Upper Volga Regional Center for Physical and Chemical Research" of Institute of Solution Chemistry of G.A. Krestov of Russian Academy of Science. Mass spectra were recorded on a Shimadzu Axima Confidence time-of-flight mass spectrometer (MALDI-TOF) of the collective laboratory of ISUCT. Thin layer chromatography (TLC) was performed on Silufol plates.

The measurement technique of photo-oxidative destruction was as following. Using a gravimetric method, we prepared a solution of the studied compound in benzene $\left(C \approx 2 \cdot 10^{-5} \mathrm{~mol} / \mathrm{l}\right)$ and recorded its electronic absorption spectrum. The cuvette with the solution was set to a thermostatted compartment of the illuminator equipped with a Carl Zeiss JENA light filter with a transmission of $365 \mathrm{~nm}$. The power density lighting of the W365 illumination was $1.47 \mathrm{~mW} / \mathrm{cm}^{2}$ (UV power meter LH-106), the illumination area was $2.02 \mathrm{~cm}^{2}$. The spectral changes in the solution of the studied substance were registered at equal intervals of irradiation for 30-300 minutes, which made it possible to estimate the kinetics of its photooxidative degradation (see Figure 1). Based on the dependence of the change in current optical density $\left(A_{t}\right)$ on the illumination time ( $\mathrm{t})$ and the known initial $\left(A_{\mathrm{o}}\right)$ optical density, the observed $\left(k_{\mathrm{ob}}\right)$ rate constant of the photooxidative destruction of the chromophore was calculated: $k_{\mathrm{obs}}=\ln \left(A_{\mathrm{o}} / A_{\mathrm{t}}\right) / \mathrm{t}$. A similar approach was applied in work. ${ }^{[17]}$ A half-life period was defined as the time during of which the compound destroys with a $50 \%$ probability, i.e. $0.5 \cdot A_{\mathrm{t}} / A_{0}$.

Electrochemical measurements have been performed in a YES-2 three-electrode electrochemical cell. A saturated silver/ silver chloride electrode served as a reference electrode, and a platinum electrode was used as a polarizing electrode. The working electrode is a carbon-graphite rod, the lateral surface of which is isolated by a fluoroplastic sheath. An active mass (thickness $0.2-0.3 \mathrm{~mm}$ ) prepared in alcohol solution was applied to the working, end surface of the electrode $\left(\mathrm{S}=0.64 \mathrm{~cm}^{2}\right)$. The active mass included: carbon carrier (CTE - carbon technical element P-514 (STST 7885-86) with ash content $0.45 \%$ ), a suspension of fluoroplastic (6\% OP-4D) and the investigated corrole, in a mass ratio of 7:2:1. The final heating of the active mass deposited on the electrode was carried out at a temperature of $573 \mathrm{~K}$ for one minute.

Measurements were carried out on the basis of the P-30J potentiometer-galvanostat and a personal computer with a hardware-software complex. At the studying of redox processes tak- ing place on the surface of the original and modified electrodes, the electrolyte was first deairated with argon $(99.99 \%)$ by bubbling at a rate $(0.14 \mathrm{~m} / \mathrm{s})$ for 40 minutes. Then, the working electrode was immersed in the electrolyte, and cyclic voltammograms were recorded in the potential range $0.5-1.5 \mathrm{~V}$. After the completing the measurements in an argon atmosphere, gaseous oxygen was transferred into the electrolyte. The fixing of the potentials of the cathode $\left(E_{\text {cat }}\right)$ and anode $\left(E_{\text {an }}\right)$ maxima for the electrode processes with the participation of the studied compounds was carried with accuracy of $\pm 0.01 \mathrm{~V}$.

5,10,15-Triphenylcorrole ( $1, \boldsymbol{R}=\boldsymbol{P h})$. (1) Synthesis is according to the method. ${ }^{[7]}$ To a stirred solution of $5.0 \mathrm{ml}(72.2 \mathrm{mmol})$ and $0.83 \mathrm{ml}(8.3 \mathrm{mmol})$ benzaldehyde into $30 \mathrm{ml}$ of methylene chloride under argon atmosphere, $0.02 \mathrm{ml}$ of trifluoroacetic acid was added. The reaction mixture was stirred two hours, after $1.57 \mathrm{~g}$ $(6.4 \mathrm{mmol})$ of $p$-chloranil and resulting solution was stirred during 0.5 hour. The solvent was distilled off on a rotary evaporator, the excess of pyrrole was distilled off with water vapor, the dirty product was filtered and dried in air. The residue was dissolved in methylene chloride and purified by column chromatography on silica gel, eluting with methylene chloride. The green fraction was evaporated and the product was precipitated with methanol. Yield 146 mg (10\%).

(2) Synthesis was carried out with changes in the original method, ${ }^{[9]} 0.5 \mathrm{ml}(5.0 \mathrm{mmol})$ of benzaldehyde and $0.7 \mathrm{ml}$ $(10.0 \mathrm{mmol})$ of pyrrole were dissolved in a mixture of $200 \mathrm{ml}$ of methanol and $200 \mathrm{ml}$ of water, while argon was passed through the mixture, then $4.3 \mathrm{ml}$ of conc. hydrochloric acid were added, and stirred at room temperature in an inert atmosphere for three hours, the resulting precipitate was filtered, dissolved in chloroform, washed with water, dried with sodium sulfate, and diluted to $300 \mathrm{ml}$ with chloroform and boiled with $1.23 \mathrm{~g}(5.0 \mathrm{mmol})$ of chloranil 1 hour. Chloroform was distilled off, the residue was washed with $5 \%$ potassium hydroxide solution, water, dried in air at $70{ }^{\circ} \mathrm{C}$, dissolved in methylene chloride and chromatographed on silica gel, eluting with methylene chloride. The fraction containing corrole was evaporated, precipitated with methanol, the precipitate was filtered, washed with methanol and air dried. Yield: $267 \mathrm{mg}$ (30\%). $R_{\mathrm{f}}=0.35$ (benzene). MALDI-TOF $(\mathrm{m} / \mathrm{z})$ found: $526.43[\mathrm{M}]^{+}$, calculated: 526.64. UV-Vis (chloroform) $\lambda_{\text {max }}\left(\varepsilon \cdot 10^{-3}\right) \mathrm{nm}: 647$ (11.5), 615 (14.4), 576 (17.6), 415 (132.7). ${ }^{1} \mathrm{H}$ NMR $\left(\mathrm{rt}, \mathrm{CDCl}_{3}\right) \delta_{\mathrm{H}} \mathrm{ppm}: 8.94 \mathrm{~s}, 8.90 \mathrm{~s}, 8.60 \mathrm{~s}, 8.59 \mathrm{~s}(4 \times 2 \mathrm{H}$, $\beta-\mathrm{H}), 8.38 \mathrm{~d}(4 \mathrm{H}, J=6.0 \mathrm{~Hz}, 2.6-\mathrm{H}-5,15-\mathrm{Ph}), 8.19 \mathrm{~d}\left(2 \mathrm{H},{ }^{1} J=5.0 \mathrm{~Hz}\right.$, 2.6-H-10-Ph), 7.70-7.80 m (9H, 3,4,5-H-Ph), -1.98 bs (3H, NH).

2,3,7,13,17,18-Hexamethyl-8,12-di-n-butylbiladiene-a,c dihydrobromide (9b). To a solution of $1.3 \mathrm{~g}(4.64 \mathrm{mmol})$ of 3,3'-di- $n$ butyl-4,4'-dimethyldipyrrolyl methane $7^{[18]}$ and $1.14 \mathrm{~g}(9.26 \mathrm{mmol})$ of 2-formyl-3,4-dimethylpyrrole $(\mathbf{8 b})^{[19]}$ in $50 \mathrm{ml}$ of methanol $2.0 \mathrm{ml}$ of conc. hydrobromic acid was added and stirred for 2 hours at room temperature. The biladiene precipitate was filtered off, washed with methanol, ether, and air dried at room temperature. Yield: $2.32 \mathrm{~g}(75.9 \%)$. MALDI-TOF $(\mathrm{m} / \mathrm{z})$ found: $497.36[\mathrm{M}-2 \mathrm{HBr}+\mathrm{H}]^{+}$, calculated: 497.77. UV-Vis (chloroform) $\lambda_{\max }\left(\varepsilon \cdot 10^{-3}\right) \mathrm{nm}$ : 522 (170.4), 457 (25.4), 370 (16.8). ${ }^{1} \mathrm{H}$ NMR (rt, $\left.\mathrm{CDCl}_{3}\right) \delta_{\mathrm{H}} \mathrm{ppm}$ : 13.68 bs, 13.43 bs $(2 \times 2 \mathrm{H}, \mathrm{NH}), 7.66 \mathrm{~d}(2 \mathrm{H}, J=3.2 \mathrm{~Hz}, 1,19-\mathrm{H}), 7.26$ $\mathrm{s}(2 \mathrm{H}, 5,15-\mathrm{H}), 5.28 \mathrm{~s}\left(2 \mathrm{H}, 20-\mathrm{CH}_{2}\right), 2.56-2.62 \mathrm{~m}\left(4 \mathrm{H}, 8,12-\mathrm{CH}_{2}-\right.$ $\mathrm{Bu}), 2.33 \mathrm{~s}, 2.29 \mathrm{~s}, 2.11 \mathrm{~s}\left(3 \times 6 \mathrm{H}, \mathrm{CH}_{3}\right), 1.52-1.73 \mathrm{~m}\left(4 \mathrm{H}, \mathrm{CH}_{2}-\mathrm{Bu}\right)$, $1.18 \mathrm{sc}\left(4 \mathrm{H},{ }^{1} \mathrm{~J}=7.4 \mathrm{~Hz}, \mathrm{CH}_{2}-\mathrm{Bu}\right), 0.69 \mathrm{t}\left(6 \mathrm{H},{ }^{1} J=7.4 \mathrm{~Hz}, \mathrm{CH}_{3}-\mathrm{Bu}\right)$.

7,13-Dimethyl-8,12-di-n-butylbiladiene-a,c dihydrobromide (9a) was obtained similarly using $0.9 \mathrm{~g}(9.46 \mathrm{mmol})$ of 2-formylpyrrole (8a). ${ }^{[20]}$ Yield: $2.2 \mathrm{~g}(80.4 \%)$. MALDI-TOF $(\mathrm{m} / \mathrm{z})$ found: $441.58[\mathrm{M}-2 \mathrm{HBr}+\mathrm{H}]^{+}$, calculated: 441.64. UV-Vis (chloroform) $\lambda_{\max }\left(\varepsilon \cdot 10^{-3}\right) \mathrm{nm}: 509$ (104.4), 445 (41.5), 411 (60.2). ${ }^{1} \mathrm{H}$ NMR (rt, $\left.\mathrm{CDCl}_{3}\right) \delta_{\mathrm{H}} \mathrm{ppm}: 14.28 \mathrm{bs}, 13.91 \mathrm{bs}(2 \times 2 \mathrm{H}, \mathrm{NH}), 7.86 \mathrm{~s}, 7.34 \mathrm{~s}$, $7.23 \mathrm{~s}(3 \times 2 \mathrm{H}, 1,2,3,17,18,19-\mathrm{H}), 6.61 \mathrm{~s}(2 \mathrm{H}, 5,15-\mathrm{H}), 5.36 \mathrm{~s}(2 \mathrm{H}$, $\left.20-\mathrm{CH}_{2}\right), 2.63 \mathrm{t}\left(4 \mathrm{H}, J=7.2 \mathrm{~Hz}, \mathrm{CH}_{2}-\mathrm{Bu}\right), 2.30 \mathrm{~s}\left(6 \mathrm{H}, \mathrm{CH}_{3}\right), 1.19 \mathrm{qv}$ (4H, $\left.J=7.2 \mathrm{~Hz}, \mathrm{CH}_{2}-\mathrm{Bu}\right), 0.86-0.94 \mathrm{~m}\left(4 \mathrm{H}, \mathrm{CH}_{2}-\mathrm{Bu}\right), 0.68 \mathrm{t}(6 \mathrm{H}$, $\left.J=7.2 \mathrm{~Hz}, \mathrm{CH}_{3}-\mathrm{Bu}\right)$. 
7,13-Dimethyl-8,12-diethylbiladiene-a,c dihydrobromide was obtained similarly, from $0.9 \mathrm{~g}$ (3.91 mmol) of 3,3'-diethyl-4,4'dimethyldipyrrolylmethane ${ }^{[18]}$ and $0.75 \mathrm{~g}(7.8 \mathrm{mmol})$ of 2-formylpyrrole. Yield: $1.4 \mathrm{~g}(66.7 \%)$. MALDI-TOF $(\mathrm{m} / \mathrm{z})$ found: 385.27 $[\mathrm{M}-2 \mathrm{HBr}+\mathrm{H}]^{+}$, calculated: 385.53. UV-Vis (chloroform) $\lambda_{\text {max }}$ $\left(\varepsilon \cdot 10^{-3}\right) \mathrm{nm}: 508$ (12.1), 404 (7.6), 410 (17.9). ${ }^{1} \mathrm{H} \mathrm{NMR}\left(\mathrm{rt}, \mathrm{CDCl}_{3}\right) \delta_{\mathrm{H}}$ ppm: $14.17 \mathrm{bs}, 13.82$ bs $(2 \times 2 \mathrm{H}, \mathrm{NH}), 7.86 \mathrm{~s}, 7.36 \mathrm{~s}, 7.25 \mathrm{~s}(3 \times 2 \mathrm{H}$, 2,3,4,17,18,19-H), $6.62 \mathrm{~s}(2 \mathrm{H}, 5,15-\mathrm{H}), 5.38 \mathrm{~s}\left(2 \mathrm{H}, 10-\mathrm{CH}_{2}\right), 2.62 \mathrm{q}$ $\left(4 \mathrm{H}, J=7.5 \mathrm{~Hz}, \mathrm{CH}_{2}-\mathrm{Et}\right), 2.31 \mathrm{~s}\left(6 \mathrm{H}, 7,13-\mathrm{CH}_{3}\right), 0.74 \mathrm{t}(6 \mathrm{H}, J=7.5 \mathrm{~Hz}$, $\left.\mathrm{CH}_{3}-\mathrm{Et}\right)$.

2,3,7,13,17,18-Hexamethyl-8,12-di-n-butylcorrole

(6b) (1) $0.3 \mathrm{~g}(0.46 \mathrm{mmol})$ of biladiene $9 \mathrm{~b}$ and $0.2 \mathrm{~g}(0.84 \mathrm{mmol})$ of lead dioxide were stirred in methanol for 30 minutes at room temperature. The progress of the reaction was monitored by thin layer chromatography. After passing the reaction, $20 \mathrm{ml}$ of water was added to the mixture. The precipitate was filtered on a Buchner funnel, washed with water and dried in air. The dried precipitate was dissolved in methylene chloride, chromatographed on alumina (Brockman grade II). The corrole fraction was evaporated, precipitated with methanol, the precipitate was filtered and air dried. Yield: $126 \mathrm{mg}(55.5 \%)$.

(2) $0.3 \mathrm{~g}(0.46 \mathrm{mmol})$ of biladiene $9 \mathrm{~b}$ and $55 \mathrm{mg}(0.23 \mathrm{mmol})$ of $p$-chloranil were dissolved in $50 \mathrm{ml}$ of methylene chloride, $0.2 \mathrm{ml}$ of triethylamine was added, stirred at room temperature during $15 \mathrm{~min}$. The mixture was evaporated, chromatographed on silica gel, eluting with methylene chloride. The fraction was evaporated, the corrole was precipitated with methanol, the precipitate was filtered, washed with methanol and air dried. Yield: $105 \mathrm{mg}$ (46.5\%). $R_{\mathrm{f}}=0.60$ (benzene). MALDI-TOF $(\mathrm{m} / \mathrm{z})$ found: 494.40 $[\mathrm{M}]^{+}$, calculated: 494.73. UV-Vis (chloroform) $\lambda_{\max }\left(\varepsilon \cdot 10^{-3}\right) \mathrm{nm}: 593$ (23.3), 549 (19.7), 537 (20.4), 403 (shoulder) (116.2), 397 (155.9). ${ }^{1} \mathrm{H}$ NMR (rt, $\left.\mathrm{CDCl}_{3}\right) \delta_{\mathrm{H}} \mathrm{ppm:} 9.82 \mathrm{~s}(2 \mathrm{H}, 5,15-\mathrm{H}), 9.71 \mathrm{~s}(1 \mathrm{H}, 10-\mathrm{H})$, 3.88-3.99 m (4H, 7,13- $\left.\mathrm{CH}_{2}-\mathrm{Bu}\right), 3.56 \mathrm{~s}, 3.50 \mathrm{~s}, 3.43 \mathrm{~s}\left(3 \times 6 \mathrm{H}, \mathrm{CH}_{3}\right)$, 2.09-2.19 m (4H, $\left.\mathrm{CH}_{2}-\mathrm{Bu}\right), 1.67-1.78 \mathrm{~m}\left(4 \mathrm{H}, \mathrm{CH}_{2}-\mathrm{Bu}\right), 1.07-1.16 \mathrm{~m}$ $\left(6 \mathrm{H}, \mathrm{CH}_{3}-\mathrm{Bu}\right),-2.07 \mathrm{bs},-3.12$ bs $(3 \mathrm{H}, \mathrm{NH})$.

Attempts to get corrole by Licoccia method. ${ }^{[22]} 0.3 \mathrm{~g}$ $(0.46 \mathrm{mmol})$ of biladiene $9 \mathrm{~b}$ and $0.3 \mathrm{~g}(1.74 \mathrm{mmol})$ of $p$-toluenesulfonic acid were dissolved in $50 \mathrm{ml}$ of methanol, the reaction mixture was refluxed while passing air for 5 hours. The progress of the reaction was monitored by thin layer chromatography. Next, $0.2 \mathrm{~g}(3.6 \mathrm{mmol})$ of $\mathrm{KOH}$ in $2 \mathrm{ml}$ of water was added to the reaction mixture. The precipitate was filtered on a Buchner funnel, washed with water, dried in air. Then the dry precipitate was dissolved in methylene chloride, chromatographed on alumina (Brockman grade II). The fraction was evaporated, the corrole precipitated with methanol, the precipitate was filtered, washed with methanol and air dried. Yield: $50 \mathrm{mg} 21 \%$ of porphyrin mixture.

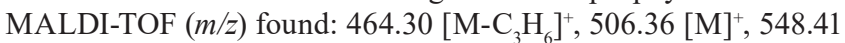
$\left[\mathrm{M}+\mathrm{C}_{3} \mathrm{H}_{6}\right]^{+}, 590.47\left[\mathrm{M}+\left(\mathrm{C}_{3} \mathrm{H}_{6}\right)_{2}\right]^{+}$, calculated: 506.46. UV-Vis $\lambda_{\mathrm{m}}$ $\left(\varepsilon \cdot 10^{-3}\right) \mathrm{nm}$ : $620.0(6.7), 566.8(8.0), 533.4(11.5), 498.3(15.1), 398.8$ (179.7).

7,13-Dimethyl-8,12-di-n-bytilcorrole (6a) was obtained analogously to the methods (1) and (2) from $0.3 \mathrm{~g}(0.5 \mathrm{mmol})$ of biladiene (9a). Yield: $8.7 \mathrm{mg}(4.0 \%)$ and $15.1 \mathrm{mg}(6.9 \%)$, respectively. $R_{\mathrm{f}}=0.83$ (benzene). MALDI-TOF $(\mathrm{m} / \mathrm{z})$ found: 438.429 $[\mathrm{M}]^{+}$, calculated: 438.62 . UV-Vis (chloroform) $\lambda_{\max }\left(\varepsilon \cdot 10^{-3}\right) \mathrm{nm}: 584$ (10.9), 544 (11.9), 537 (10.7), 404 (57.6), 390 (54.6). ${ }^{1} \mathrm{H}$ NMR (rt, $\left.\mathrm{CDCl}_{3}\right) \delta_{\mathrm{H}}$ ppm: $9.87 \mathrm{~s}(2 \mathrm{H}, 5,15-\mathrm{H}), 9.61 \mathrm{~s}(1 \mathrm{H}, 10-\mathrm{H}), 8.73 \mathrm{~s}, 8.67$ s $(2 \times 2 \mathrm{H}, 2,3,17,18-\mathrm{H}), 3.88 \mathrm{t}\left(4 \mathrm{H}, J=7.3 \mathrm{~Hz}, 8,12-\mathrm{CH}_{2}-\mathrm{Bu}\right), 3.49$ s $\left(6 \mathrm{H}, 7,13-\mathrm{CH}_{3}\right), 2.11 \mathrm{qv}\left(4 \mathrm{H}, J=7.3 \mathrm{~Hz}, \mathrm{CH}_{2}-\mathrm{Bu}\right), 1.70 \mathrm{sc}(4 \mathrm{H}$, $\left.J=7.3 \mathrm{~Hz}, \mathrm{CH}_{2}-\mathrm{Bu}\right), 1.10 \mathrm{t}\left(6 \mathrm{H}, J=7.3 \mathrm{~Hz}, \mathrm{CH}_{3}-\mathrm{Bu}\right),-0.02 \mathrm{bs},-2.77$ bs $(2+1 \mathrm{H}, \mathrm{NH})$.

7,13-Dimethyl-8,12-diethylcorrole was obtained by known for this compound methodologies. ${ }^{[12]} 0.3 \mathrm{~g}(0.55 \mathrm{mmol})$ of biladiene 9a were stirred in $200 \mathrm{mg}$ of methanol with an excess of $\mathrm{NaHCO}_{3}$ in methanol. After this, $0.1 \mathrm{~g}(0.4 \mathrm{mmol})$ of $p$-chloranil was added and mixture was stirred for 5 minutes, then $1.5 \mathrm{ml}$ of $15 \%$ solution of hydrazine hydrate was added to the mixture. The mixture was fil- tered on a Buchner funnel, dried, dissolved in methylene chloride, chromatographed on alumina (Brockman grade II). The fraction containing corrole was evaporated, precipitated with methanol. The precipitate was filtered and air dried. Yield: $12.9 \mathrm{mg}(6.1 \%) . R_{\mathrm{f}}=0.79$ (benzene). MALDI-TOF $(\mathrm{m} / \mathrm{z})$ found: $382.23[\mathrm{M}]^{+}$, calculated: 382.51. UV-Vis (chloroform) $\lambda_{\max } \mathrm{nm}\left(\varepsilon \cdot 10^{-3}\right): 584$ (16.0), 544 (18.1), 403 (107.4), 386 (102.7). ' $\mathrm{H}$ NMR (rt, $\left.\mathrm{CDCl}_{3}\right) \delta_{\mathrm{H}} \mathrm{ppm}: 9.88 \mathrm{~s}(2 \mathrm{H}$, 5,15-H), $9.62 \mathrm{~s}(1 \mathrm{H}, 10-\mathrm{H}), 8.73 \mathrm{~s}, 8.67 \mathrm{~s}(2 \times 2 \mathrm{H}, 2,3,17,18-\mathrm{H}), 3.90$ q $\left(4 \mathrm{H},{ }^{1} \mathrm{~J}=8.0 \mathrm{~Hz}, 8,12-\mathrm{CH}_{2}-\mathrm{Et}\right), 3.50 \mathrm{~s}\left(6 \mathrm{H}, 7,13-\mathrm{CH}_{3}\right), 1.77 \mathrm{t}(6 \mathrm{H}$, $\left.{ }^{1} J=8.0 \mathrm{~Hz}, \mathrm{CH}_{3}-\mathrm{Et}\right),-0.02 \mathrm{bs},-2.81 \mathrm{bs}(2+1 \mathrm{H}, \mathrm{NH})$.

$\mathrm{Cu}$ (III) 5,10,15-Triphenylcorrole. $20 \mathrm{mg}(0.038 \mathrm{mmol})$ of 1 $(\mathbf{R}=\mathbf{P h})$ and $0.1 \mathrm{~g}(0.55 \mathrm{mmol})$ of copper acetate in THF were stirred at room temperature for 10-15 minutes (ESA control). Follow, the mixture was evaporated to dryness, the residue was dissolved in benzene and chromatographed on silica gel, eluting with benzene. The benzene was distilled off, the complex was precipitated with methanol, the precipitate was filtered and air dried. Yield: $14 \mathrm{mg}(63.2 \%) . R_{\mathrm{f}}=0.86$ (benzene). MALDI-TOF $(\mathrm{m} / \mathrm{z})$ found: $586.36[\mathrm{M}-\mathrm{H}]^{+}$, calculated: 586.16 . UV-Vis (chloroform) $\lambda_{\text {max }} \mathrm{nm}$ $\left(\varepsilon \cdot 10^{-3}\right): 623(6.1), 541(9.0), 410(119.9)$.

Ag(III) 5,10,15-Triphenylcorrole was obtained by methodology. ${ }^{[23]} 50 \mathrm{mg}(0.1 \mathrm{mmol})$ of $\mathbf{1}(\mathbf{R}=\mathbf{P h})$ and $55 \mathrm{mg}(0.33 \mathrm{mmol})$ of silver acetate were dissolved in $10 \mathrm{ml}$ of pyridine and the mixture was refluxed for 0.5 hours (ESA control). The reaction mixture was cooled, poured into water, the sodium acetate was added to coagulation of precipitate. Obtained product was filtered, washed with water and air dried. The metal complex was dissolved in methylene chloride and chromatographed on alumina (Brockman grade II) by elution with methylene chloride. The eluate was evaporated, the complex was precipitated with methanol, the precipitate was filtered off, washed with methanol and dried. Yield: $29 \mathrm{mg}(46 \%) . R_{\mathrm{f}}=0.88$ (benzene). MALDI-TOF $(\mathrm{m} / \mathrm{z})$ found: 632.08 $[\mathrm{M}+\mathrm{H}]^{+}$, calculated: 632.49. UV-Vis (chloroform) $\lambda_{\text {max }} \mathrm{nm}$ $\left(\varepsilon \cdot 10^{-3}\right): 582.5$ (10.75), 559.4 (10.36), 424.9 (112.4).

$\mathrm{Sb}$ (III) 5,10,15-Triphenylcorrole was obtained in a similar way from $50 \mathrm{mg}(0.1 \mathrm{mmol})$ of $\mathbf{1}(\mathbf{R}=\mathbf{P h})$ and $120 \mathrm{mg}(0.33 \mathrm{mmol})$ of antimony(III) bromide. The duration of the reaction was 2.5 hours (ESA control). Yield: $36 \mathrm{mg}(55.5 \%) . R_{\mathrm{f}}=0.86$ (benzene). MALDI-TOF $(\mathrm{m} / \mathrm{z})$ found: $644.342[\mathrm{M}-\mathrm{H}]^{+}$, calculated: 644.36 . UV-Vis (chloroform) $\lambda_{\text {max }} \mathrm{nm}\left(\varepsilon \cdot 10^{-3}\right): 663$ (29.3), 616 (shoulder) (9.4), 541 (10.2), 461 (113.1), 441 (111.8).

Mn(III) 5,10,15-Triphenylcorrole. $100 \mathrm{mg}(0.19 \mathrm{mmol})$ of $\mathbf{1}$ $(\mathbf{R}=\mathbf{P h})$ and $931 \mathrm{mg}(3.8 \mathrm{mmol})$ of manganese acetate tetrahydrate were refluxed in $30 \mathrm{ml}$ DMF during 3 hours (ESA control). Follow, the reaction mixture was cooled, poured into water, the sodium acetate was added. Obtained complex was filtered, washed by water and air dried. The precipitate was dissolved in methylene chloride and chromatographed on alumina (Brockman grade II), using methylene chloride. The eluate was evaporated and the complex was precipitated with methanol, filtered, washed with methanol and dried. Yield: $83.5 \mathrm{mg}(76 \%) . R_{\mathrm{f}}=0.66$ (benzene-methanol, 10:1). MALDI-TOF $(\mathrm{m} / \mathrm{z})$ found: $578.24[\mathrm{M}]^{+}$, calculated: 578.55 . UV-Vis (chloroform) $\lambda_{\text {max }} \mathrm{nm}\left(\varepsilon \cdot 10^{-3}\right): 662.6(10.04), 501.5$ (10.54), 439.2 (111.4).

$\mathrm{Fe}$ (III) 5,10,15-Triphenylcorrole was synthesized by similar way from $100 \mathrm{mg}$ of $\mathbf{1}(\mathbf{R}=\mathbf{P h})$ and $750 \mathrm{mg}(3.8 \mathrm{mmol})$ of iron(III) chloride hexahydrate. Yield: $63.8 \mathrm{mg}(58 \%) . R_{\mathrm{f}}=0.88$ (benzene). MALDI-TOF $(\mathrm{m} / \mathrm{z})$ found: 579.15 [M] $]^{+}$, calculated: 579.46 . UV-Vis (chloroform) $\lambda_{\text {max }} \mathrm{nm}\left(\varepsilon \cdot 10^{-3}\right): 509.2$ (10.04), 401.3 (11.37), 375.2 (111.4).

Co(III) 5,10,15-Triphenylcorrole. $50 \quad \mathrm{mg} \quad\left(\begin{array}{lll}0.1 & \mathrm{mmol})\end{array}\right.$ of $\mathbf{1}(\mathbf{R}=\mathbf{P h}), 100 \mathrm{mg}(0.38 \mathrm{mmol})$ of cobalt(II) tetrahydrate acetate and $100 \mathrm{mg}(0.38 \mathrm{mmol})$ of triphenylphosphine were dissolved in methanol and refluxed for 3 hours (ESA control). Then the reaction mixture was cooled, poured into water, and the sodium acetate was added. Obtained complex was filtered, washed by water and air dried. The precipitate was dissolved in methylene chloride and chromatographed on alumina (Brockman grade II) using 
methylene chloride. The eluate was evaporated and the complex was precipitated with methanol, filtered, washed with methanol and dried. Yield: $29.5 \mathrm{mg}(53.3 \%) . R_{\mathrm{f}}=0.91$ (benzene). MALDITOF $(\mathrm{m} / \mathrm{z})$ found: $582.59[\mathrm{M}]^{+}$, calculated: 582.55 . UV-Vis (chloroform) $\lambda_{\max } \mathrm{nm}\left(\varepsilon \cdot 10^{-3}\right): 627$ (35.7), 584 (14.5), 457 (83.0), 437 (99.1). $\mathrm{Cu}(I I I) \quad 2,3,7,13,17,18$-Hexamethyl-8,12-di-n-butylcorrole. $30 \mathrm{mg}(0.06 \mathrm{mmol})$ of $\mathbf{6 b}$ and $44 \mathrm{mg}(0.12 \mathrm{mmol})$ of copper acetylacetonate were dissolved in $20 \mathrm{ml}$ of methylene chloride and stirred at the room temperature for 4 hours (ESA control). Then the reaction mixture was chromatographed on alumina (Brockman grade II) using methylene chloride. The eluate was evaporated and the complex was precipitated with methanol, filtered, washed with methanol and dried. Yield: $29.6 \mathrm{mg}(89.3 \%)$. $R_{\mathrm{f}}=0.74$ (benzene). MALDI-TOF $(\mathrm{m} / \mathrm{z})$ found: $554.49[\mathrm{M}-\mathrm{H}]^{+}$, calculated: 554.24. UV-Vis (chloroform) $\lambda_{\text {max }} \mathrm{nm}\left(\varepsilon \cdot 10^{-3}\right)$ : 549 (11.8), 500 (shoulder) (9.1), 397 (104.4).

Sb(III) 2,3,7,13,17,18-Hexamethyl-8,12-di-n-butylcorrole. $50 \mathrm{mg}(0.1 \mathrm{mmol})$ of $\mathbf{6 a}$ and $120 \mathrm{mg}(0.33 \mathrm{mmol})$ of antimony(III) bromide were dissolved in $10 \mathrm{ml}$ of pyridine and the mixture was refluxed to change color from crimson to green (ESA control). Then the reaction mixture was cooled, poured into water, and the sodium acetate was added. Obtained complex was filtered, washed by water and air dried. The precipitate was dissolved in methylene chloride and chromatographed on alumina (Brockman grade II), using methylene chloride. The eluate was evaporated and the complex was precipitated with methanol, filtered, washed with methanol and dried. Yield: $51.7 \mathrm{mg}(84.3 \%) . R_{\mathrm{f}}=0.71$ (benzene). MALDI-TOF $(\mathrm{m} / \mathrm{z})$ found: $612.50[\mathrm{M}-\mathrm{H}]^{+}$, calculated: 612.44. UV-Vis (chloroform) $\lambda_{\max } \mathrm{nm}\left(\varepsilon \cdot 10^{-3}\right): 663$ (29.3), 616 (9.4), 541 (10.2), 461 (113.1), 441 (111.8).

\section{Results and Discussion}

\section{The Synthesis of meso-Triphenylcorrole}

The synthesis of 5,10,15-triphenylcorrole $(\mathbf{1}, \mathbf{R}=\mathbf{P h})$ was carried out by two ways. The first was the method of Lee-Gryko ${ }^{[6]}$ (1) and the second was the method of GrykoKozzarna $^{[8]}$ (2) (Scheme 1, Table 1). Moreover, it was found that the second, two-staged method gives a much higher yield of corrole and is preferable.

\section{The Synthesis of $\beta$-Alkyl Substituted Corroles}

The $\beta$-alkyl substituted corroles 2 were synthesized by the oxidizing cyclization of biladienes- $a, c$ dihydrobromides 4 using different oxidizing agents (Scheme 2). 2,3,7,13,17,18-Hexamethyl-8,12-di-n-butylcorrole $\mathbf{6 b}$ was studied as model compound. It has high solubility in nonpolar organic solvents and is easily separated from the reaction mass.
Table 1. The synthesis of meso-triphenylcorrole 1.

\begin{tabular}{cc}
\hline Method & Yield (\%) \\
\hline 1 & 10.0 \\
2 & 30.0 \\
\hline
\end{tabular}

Initial $\quad 2,3,7,13,17,18$-hexamethyl-8,12-di- $n$-butylbiladiene- $a, c$ dihydrobromide $9 \mathbf{b}^{[21]}$ was obtained by the condensation of 3,3'-di- $n$-butyl-4,4'-dimethyldipyrrolylmethane ${ }^{[18]}$ 7 with 2-formyl-3,4-dimethylpyrrole ${ }^{[19]} \mathbf{8 b}$ in methanol in the presence of hydrobromic acid (Scheme 4).

While carrying out the oxidative cyclization reaction of biladiene- $a, c$ 9b in methanol, four different oxidizers were tested (Scheme 4). It was found out that the oxidation reaction was after the conversion of biladiene- $a, c$ dihydrobromide, $9 \mathrm{~b}$ into free base under the influence of ammonia $\left(N\right.$ 1), sodium bicarbonate $\left(\begin{array}{l}N \\ 2\end{array}\right)$ or triethylamine $(N$ 3). It was determined, that using chloranil as an oxidizing agent at the molar ratio of biladiene to chloranil is 1:1, the yield of corrole is maximum (N3), however, at the ratio of 1:2 corrole was not formed. The best results were obtained when using lead(IV) dioxide as an oxidizing agent without a basic agent $(N 4)$.

In the work of Licoccia et al. ${ }^{[22]}$ for obtaining corroles it was suggested to use dihydrobromide biladienes in the presence of acidic agents especially $p$-toluenesulfonic acid in boiling ethanol instead of a base. In this work the air oxygen was an oxidizing agent. Our studies have shown $(N 5)$ that in this case instead of the corrole only a mixture of porphyrins was obtained, what was proved by UV-Vis spectra. The obtained porphyrins have different number of butyl residues, as it was shown by mass spectra (see Experimental part). The formation of the mixture of porphyrins is associated with the acidolysis of oxidized biladiene. ${ }^{[5]}$

Moreover, we tried to synthesize 7,13-dimethyl8,12-di-n-butylcorrole 6a, which doesn't have alkyl substituents at $\beta$-positions of two pyrrole cycles. The initial 7,13-dimethyl-8,12-di- $n$-butylbiladiene- $a, c$ dihydrobromide 9a was obtained by the interaction of 3,3'-di- $n$-butyl-4,4'dimethyldipyrrolylmethane with 2-formylpyrrole $\mathbf{8 a}^{[20]}$ (Scheme 4). On the final step of corrole 6a synthesis we tested three most effective oxidation methods: oxidizing by lead dioxide, air oxygen (Paolesse method ${ }^{[12]}$ ) and $p$-chloranil in methylene chloride in the presence of triethylamine (Table 3).

However, in all cases, the yield of corrole was very low. In the experiment it was found out that the method of lead dioxide oxidation which was the most successful in the syn-

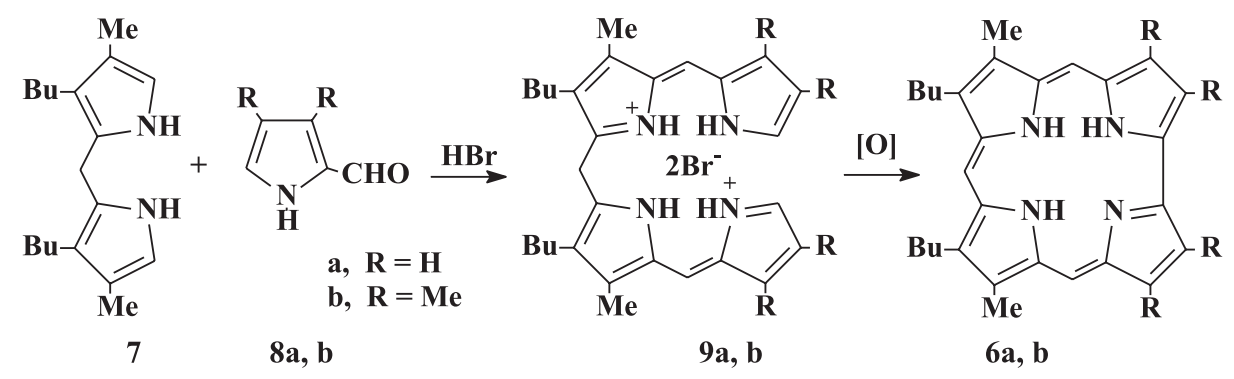

Scheme 4. 
Table 2. The synthesis of 2,3,7,13,17,18-hexamethyl-8,12-di- $n$-butylcorrole (6b).

\begin{tabular}{ccccc}
\hline$N$ & Oxidizing agent & Reagent & $\begin{array}{c}\text { Conditions and duration } \\
\text { of synthesis }\end{array}$ & Yield (\%) \\
\hline 1 & $\mathrm{~K}_{3}\left[\mathrm{Fe}(\mathrm{CN})_{6}\right]$ & $\mathrm{NH}_{3}$ & reflux, 5 min & 43.6 \\
2 & $p$-chloranil & $\mathrm{NaHCO}_{3}$ & r.t., 5 min & 42.3 \\
3 & $\mathrm{NEO}_{3}$ & - & r.t., 15 min & 46.5 \\
4 & $\mathrm{O}_{2}$ of air & $p$-toluenesulfonic acid & r.t., 30 min & 55.5 \\
5 & & reflux, $5 \mathrm{~h}$ & 21.5 (mixture of porphyrins) \\
\hline
\end{tabular}

thesis of $2,3,6,7,13,17$-hexamethyl-8,12-di- $n$-butylcorrole was less effective in the synthesis of 7,13-dimethyl-8,12-di$n$-butylcorrole.

To find out the reason of the low yield of tetraalkylcorroles, 7,13-dimethyl-8,12-diethylcorrole was synthesized according to the procedure described in work. ${ }^{[12]}$ However, even in this case, the corrole was obtained with an yield of only $6.1 \%$, which is much lower than the $61 \%$ claimed by the authors. We believe that the low yield of tetraalkylsubstituted corroles, as well as similar to them porphyrins, ${ }^{[2]}$ is associated with an increased reactivity of the free $\beta$-pyrrole positions of intermediate products of synthesis.

\section{The Synthesis of Corrole Metal Complexes}

In order to assess the coordination properties of mesophenyl- and $\beta$-alkylcorroles, the complexation of salts of various metals with meso-5,10,15-triphenylcorrole $\left(\mathrm{H}_{3} \mathrm{Ph}_{3} \mathrm{Cor}\right)$ and 2,3,6,7,13,17-hexamethyl-8,12-di- $n$-butylcorrole $\left(\mathrm{H}_{3} \mathrm{Me}_{6}\right.$ $\mathrm{Bu}_{2} \mathrm{Cor}$ ) in organic solvents was carried out (Table 4).

From the data of Table 4 it follows that the coordination properties of the ligands 5,10,15-triphenylcorrole and 2,3,6,7,13,17-hexamethyl-8,12-di- $n$-butylcorrole are very different. The complexes of 5,10,15-triphenylcorrole with $\mathrm{Ag}(\mathrm{III}), \mathrm{Mn}(\mathrm{III}), \mathrm{Co}(\mathrm{III})$ were obtained in high yields, whereas analogous compounds with 2,3,6,7,13,17-hexamethyl-8,12-di- $n$-butylcorrole have not been obtained.

Iron metal complex with 2,3,6,7,13,17-hexamethyl8,12 -di- $n$-butylcorrole was obtained in trace amounts. In the obtaining of copper complexes with 2,3,6,7,13,17-hexamethyl-8,12-di- $n$-butylcorrole we replaced the copper acetate which is the most commonly used for these purposes by copper acetylacetonate, because it is highly soluble in organic solvents, unlike copper acetate. This allowed us to carry out the reaction in methylene chloride in mild conditions at room temperature, but the yield of the metal complex did not change much.

\section{The Stability of Corroles to Photooxidative Destruction}

Stability to photooxidation is one of the main characteristics of a chromophore (in our case, corrole) which describes the kinetic stability of a compound in solution

Table 3. The synthesis of 7,13-dimethyl-8,12-di-n-bytilcorrole $\mathbf{6 a}$.

\begin{tabular}{ccccc}
\hline $\mathrm{N}$ & Base & Oxidizing agent & Conditions & Yield (\%) \\
\hline 1 & $\mathrm{NaHCO}_{3}$ & chloranil & r.t., 5 min. $\mathrm{MeOH}$ & 6.0 \\
2 & $\mathrm{NEt}_{3}$ & $\mathrm{PbO}_{2}$ & r.t., 15 min $\mathrm{CH}_{2} \mathrm{Cl}_{2}$ & 6.9 \\
3 & - & r.t., 30 min & 4.0 \\
\hline
\end{tabular}

Table 4. The synthesis of metal complexes of 5,10,15-triphenylcorrole and 2,3,6,7,13,17-hexamethyl-8,12-di-n-butylcorrole.

\begin{tabular}{|c|c|c|c|c|}
\hline Ligand & Salt & Reaction condition & Complex & Yield $(\%)$ \\
\hline \multirow{6}{*}{$\mathrm{H}_{3} \mathrm{Ph}_{3} \mathrm{Cor}$} & $\mathrm{Cu}(\mathrm{OAc})_{2}$ & THF, r.t. & $\mathrm{CuPh}_{3} \mathrm{Cor}$ & 97 \\
\hline & AgOAc & Pyridine, $80{ }^{\circ} \mathrm{C}$ & $\mathrm{AgPh}_{3} \mathrm{Cor}$ & 46 \\
\hline & $\mathrm{FeCl}_{2}$ & DMF, reflux & $\mathrm{FePh}_{3} \mathrm{Cor}$ & 58 \\
\hline & $\mathrm{Mn}(\mathrm{OAc})_{2}$ & DMF, reflux & $\mathrm{MnPh}_{3} \mathrm{Cor}$ & 76 \\
\hline & $\mathrm{Co}(\mathrm{OAc})_{2}$ & $\mathrm{DMF}, \mathrm{PPh}_{3}$, reflux & $\mathrm{CoPh}_{3} \mathrm{Cor}\left(\mathrm{PPh}_{3}\right)$ & 53 \\
\hline & $\mathrm{SbBr}_{3}$ & Pyridine, reflux & $\mathrm{SbPh}_{3} \mathrm{Cor}$ & 56 \\
\hline \multirow{6}{*}{$\mathrm{H}_{3} \mathrm{Me}_{6} \mathrm{Bu}_{2} \mathrm{Cor}$} & $\mathrm{Cu}(\mathrm{AcAc})_{2}$ & $\mathrm{CH}_{2} \mathrm{Cl}_{2}$, reflux & $\mathrm{CuMe}_{6} \mathrm{Bu}_{2} \mathrm{Cor}$ & 89 \\
\hline & $\mathrm{SbBr}_{3}$ & Pyridine, reflux & $\mathrm{SbMe}_{6} \mathrm{Bu}_{2} \mathrm{Cor}$ & 84 \\
\hline & $\mathrm{FeCl}_{2}$ & DMF, reflux & $\mathrm{FeMe}_{6} \mathrm{Bu}_{2} \mathrm{Cor}$ & trace \\
\hline & $\mathrm{AgOAc}$ & Pyridine, $80^{\circ} \mathrm{C}$ & & \\
\hline & $\mathrm{Mn}(\mathrm{OAc})_{2}$ & DMF, reflux & & \\
\hline & $\mathrm{Co}(\mathrm{OAc})_{2}$ & $\mathrm{DMF}, \mathrm{PPh}_{3}$ reflux & & \\
\hline
\end{tabular}


under the influence of UV irradiation in the presence of atmospheric oxygen. Being $\pi$-electron-rich and less aromatic compounds compared to the porphyrins, ${ }^{[1]}$ the corroles, both as free ligands and as complexes, are chemically and thermally less stable. ${ }^{[2]}$ Therefore, the photosensitivity of corroles in comparison with porphyrins is expected to be greater. ${ }^{[25,26]}$

In the present work, we have studied the comparative stability of triphenylcorroles and their complexes with some metals to photooxidative destruction. The objects of study were 5,10,15-triphenylcorrole, its $\mathrm{Cu}, \mathrm{Ag}, \mathrm{Fe}, \mathrm{Mn}, \mathrm{Sb}$ complexes, as well as 2,3,7,13,17,18-hexamethyl-8,12-di- $n$-butylcorrole and its $\mathrm{Cu}$ and $\mathrm{Sb}$ complexes. Benzene was chosen as the medium for studying the process, because it excludes acid-base interactions of the solute with the solvent, typical of some corrole ligands. ${ }^{[27]}$ The Figure 1 shows that the spectral changes for triphenylcorrole and its Fe complex depend on the irradiation time.

The obtained results (Table 5) show, that corrole ligands do not have high stability to photooxidative destruction. The half-life time $\left(t_{1 / 2}\right)$ of 5,10,15-triphenylcorrole $\mathbf{1},(\mathbf{R}=\mathbf{P h})$ and 2,3,7,13,17,18-hexamethyl-8,12-di- $n$-butylcorrole $\mathbf{6 b}$ is 2.1 and 0.6 hours, correspondingly, which is apparently due to the structural features of the macrocycle of the molecule. As it was mentioned above, these features include the $\pi$-electron excess character of the molecule, the non equal distribution of electron density in the macrocycle, which lead to significant dipole moments of these molecules, more conformational mobility, than that of the porphyrins, etc.

The observed rate constant $\left(k_{o b}\right)$ of the photooxidative destruction for $\mathrm{H}_{3} \mathrm{Ph}_{3}$ Cor and $\mathrm{H}_{3} \mathrm{Me}_{6} \mathrm{Bu}_{2}$ Cor is $10.5 \cdot 10^{-5}$ and $33.6 \cdot 10^{-5}\left(\mathrm{~s}^{-1}\right)$, correspondingly. That is, $\mathrm{H}_{3} \mathrm{Ph}_{3}$ Cor having electron-withdrawing phenyl fragments in the mesopositions of the molecule, is almost three times more resistant to photooxidative destruction than its $\beta$-alkyl substituted analogue $\left(\mathrm{H}_{3} \mathrm{Me}_{6} \mathrm{Bu}_{2} \mathrm{Cor}\right)$. It can be supposed that the increase of electron density in the macrocycle leads to the transition of electrons to the excited state under the influence of light quanta, which in turn leads to the increase of the concentration of active oxygen in the solution and to the accelerated degradation of the chromophore.

The formation of coordination bond of $d$-metal atoms with nitrogen atoms of corroles, apparently, accompanies with the redistribution of the excess electron density

Table 5. Quantitative characteristics of the photostability of corroles and their complexes in benzene $\left(C_{\mathrm{m}} \approx 2 \cdot 10^{-5} \mathrm{~mol} \cdot \mathrm{l}^{-1}\right)$.

\begin{tabular}{ccc}
\hline Compound & $k_{\text {obs }} \cdot 10^{-5}, \mathrm{~s}^{-1}$ & $t_{1 / 2}$, hour \\
\hline $\mathrm{H}_{3} \mathrm{Ph}_{3}$ Cor & $10.5 \pm 1.9$ & 2.1 \\
$\mathrm{CuPh}_{3}$ Cor & $0.54 \pm 0.12$ & 40.7 \\
$\mathrm{AgPh}_{3}$ Cor & $0.59 \pm 0.14$ & 33.7 \\
$\mathrm{FePh}_{3}$ Cor & $0.68 \pm 0.11$ & 23.3 \\
$\mathrm{MnPh}_{3} \mathrm{Cor}$ & $0.23 \pm 0.19$ & 138.6 \\
$\mathrm{SbPh}_{3}$ Cor & $12.6 \pm 1.8$ & 1.8 \\
$\mathrm{H}_{3} \mathrm{Me}_{6} \mathrm{Bu}_{2} \mathrm{Cor}$ & $33.6 \pm 5.8$ & 0.6 \\
$\mathrm{CuMe}_{6} \mathrm{Bu}_{2} \mathrm{Cor}$ & $0.33 \pm 0.05$ & 41.6 \\
$\mathrm{SbMe}_{6} \mathrm{Bu}_{2} \mathrm{Cor}$ & $25.5 \pm 2.3$ & 0.9 \\
\hline
\end{tabular}

of the ligand onto the $d$-orbital of the complexing atom. In particular, the introduction of a copper cation into the coordination cavity of corroles leads to the equally low values of the photooxidation rate constants in $\mathrm{CuPh}_{3}$ Cor and $\mathrm{CuMe}_{6} \mathrm{Bu}_{2} \mathrm{Cor}\left(0.54 \cdot 10^{-5}\right.$ and $0.33 \cdot 10^{-5} \mathrm{~s}^{-1}$, correspondingly). Consequently, the coordination of 5,10,15-triphenylcorrole and 2,3,7,13,17,18-hexamethyl-8,12-di- $n$-butylcorrole with a copper cation practically eliminates their resistance to photoxidation. From the data of Table 5, it can be concluded, that $\mathrm{Cu}$ and $\mathrm{Ag}$ triphenylcorrole complexes have a few differences in photostability.

Among the studied complexes of triphenylcorroles, the complex of manganese showed the highest resistance to photooxidative destruction (the time of half-life is 136 hours). The introduction of the antimony cation into the coordination cavity of the corroles increases the tendency of the metalcorrole to the oxidative destruction under UV irradiation, and $\mathrm{SbPh}_{3}$ Cor was twice stable than its alkyl substituted analogue. The low stability to photo destruction of metal complexes of corroles with bismuth and lead was noted in works. ${ }^{[28,29]}$

Irradiation of the $\mathrm{FePh}_{3}$ Cor solution in benzene with UV light is accompanied by a $3-5 \mathrm{~nm}$ bathochromic shift of the maximum absorption band of the complex. After 90 minutes of illumination the position of the absorption band stabilizes (Figure 1), probably due to a change in the degree of oxidation of Fe from $3^{+}$to $4^{+}$.

Thus, from the obtained results it is considered, that the stability of corrole to photooxidative destruction under UV illumination greatly depends on the nature of the functional substitution in the molecule. Complexation highly eliminates these differences in a raw of similar complexes (shown on the example of $\mathrm{Cu}$ ). The metal complexes of corroles (with the exception of $\mathrm{Sb}$ ) turned out to be significantly more resistant to photooxidative destruction compared with the corresponding ligands.

\section{Electrochemical Studies of Metal Corroles}

In the work, in continuation of previous studies on the effect of chemical modification on the electrochemical behavior of metal-meso-triphenylcorroles, especially the nature of the metal $(\mathrm{L}) \mathrm{MPh}_{3} \mathrm{Cor},(\mathrm{L}) \mathrm{M}=\mathrm{Cu},(\mathrm{DMF} \mathrm{H})+$ $\mathrm{Zn},(\mathrm{DMF}) \mathrm{Co},(\mathrm{DMF}) \mathrm{Mn},{ }^{[30]}$ electrochemistry characteristics of $\mathrm{Ag}^{\text {III }} \mathrm{Ph}_{3}$ Cor, $(\mathrm{Py}) \mathrm{Sb}^{\text {III }} \mathrm{Ph}_{3} \mathrm{Cor},{ }^{[31]}\left(\mathrm{PPh}_{3}\right) \mathrm{Co}^{\mathrm{III}} \mathrm{Ph}_{3} \mathrm{Cor},{ }^{[32]}$ and $\beta$-alkyl substituted corroles: $\mathrm{H}_{3} \mathrm{Me}_{6} \mathrm{Bu}_{2} \mathrm{Cor}, \mathrm{Cu}^{\mathrm{III}} \mathrm{Me}_{6}$ $\mathrm{Bu}_{2} \mathrm{Cor},(\mathrm{Py}) \mathrm{Sb}^{\mathrm{III}} \mathrm{Me}_{6} \mathrm{Bu}_{2} \mathrm{Cor}^{[31]}$ were studied. The influence of metal, the effect of coordination on the example of cobalt complexes, $\beta$-substituents for the behaviour of cyclic voltammograms (CVA) and the activity of compounds in the reaction of oxygen electroreduction at the interface "electrodeelectrolyte solution" have been shown.

In argon atmosphere for electrodes containing $\mathrm{Ag}^{\mathrm{III}} \mathrm{Ph}_{3} \mathrm{Cor}$, $(\mathrm{Py}) \mathrm{Sb}^{\mathrm{III}} \mathrm{Ph}_{3} \mathrm{Cor}$ and $\left(\mathrm{PPh}_{3}\right) \mathrm{Co}^{\mathrm{III}} \mathrm{Ph}_{3}$ Cor mesotriphenylcorroles, one common stage of the electroreduction (Table 6) is observed. It is connected with the addition of an electron to the $\pi$-electron system of the macrocycle.

Complexation leads to a slight shift of the redox potentials of $\mathrm{Ag}^{\mathrm{III}} \mathrm{Ph}_{3} \mathrm{Cor}$, $(\mathrm{Py}) \mathrm{Sb}^{\mathrm{III}} \mathrm{Ph}_{3}$ Cor and $\left(\mathrm{PPh}_{3}\right) \mathrm{Co}^{\mathrm{III}} \mathrm{Ph}_{3}$ Cor to negative magnitude (Table 6 , the process $\mathrm{L}^{\mathrm{a}} \leftrightarrow \mathrm{L}^{-}$). Trianionic corrole ligand is able to stabilize higher oxidation 

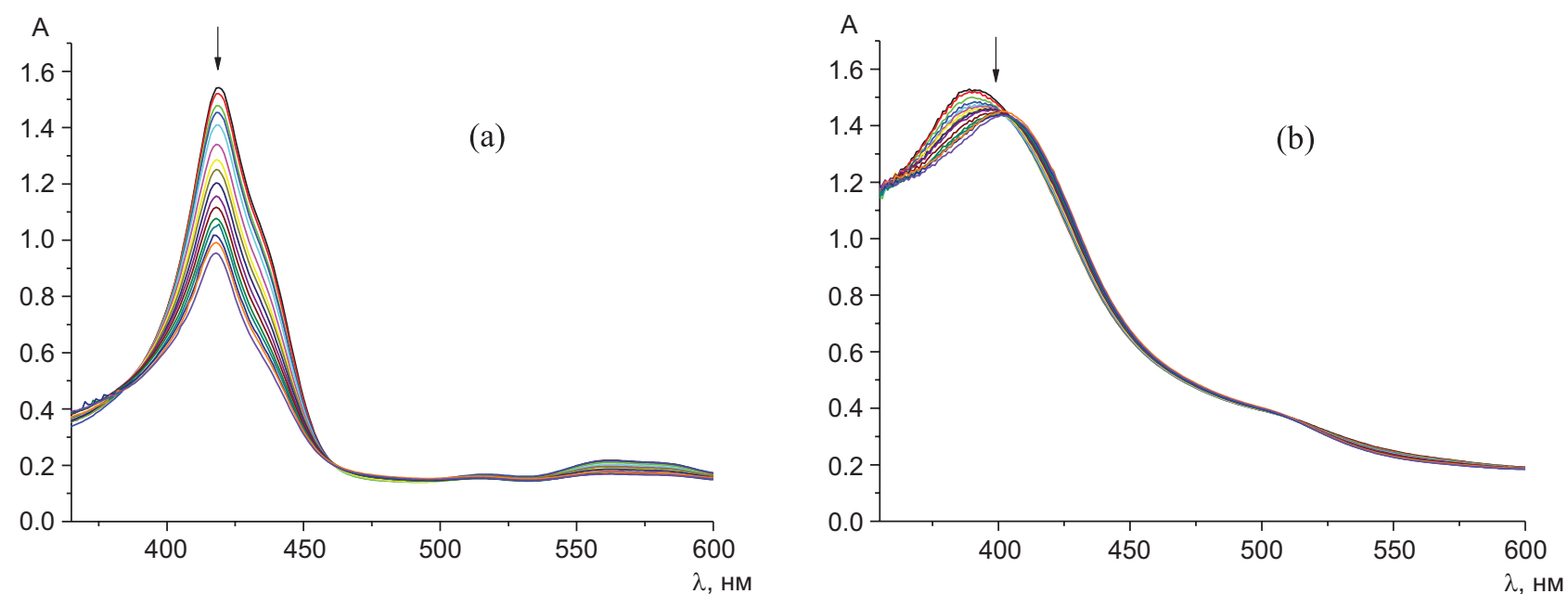

Figure 1. Spectral changes under the action of UV irradiation: (a) $-\mathrm{H}_{3} \mathrm{Ph}_{3} \mathrm{Cor}$, (b) $-\mathrm{FePh}_{3} \mathrm{Cor}$ in a solution of benzene.

states of metals compared to porphyrin. ${ }^{[27]}$ It should be noted that the degree of oxidation of the metal in complexes of corroles with highly charged metal cations, which include $\mathrm{Ag}(\mathrm{III}), \mathrm{Cu}(\mathrm{III}), \mathrm{Fe}(\mathrm{IV}), \mathrm{Mn}(\mathrm{IV}), \mathrm{Cr}(\mathrm{V})$ and others, is mainly formal due to the important role of transfer-charge interactions in the formation of $\mathrm{M}-\mathrm{N}$ bonds.

Complex (Py)Sb $\mathrm{Sb}_{3} \mathrm{Cor}$ has a distinguished cathode maximum on current-voltage curves, corresponding to the process of electroreduction of the antimony atom at $E_{1 / 2}=-0.74 \mathrm{~V}$ (Figure 2).

For the $\mathrm{Ag}^{\mathrm{III}} \mathrm{Ph}_{3} \mathrm{Cor}$ complex, on the current-voltage curves in the regarded potential range only one metal transition (III $\leftrightarrow$ II) at $E_{1 / 2}=-0.58 \mathrm{~V}$ was detected, the transition II $\leftrightarrow$ I was not registered.

For the complex of $\left(\mathrm{PPh}_{3}\right) \mathrm{Co}^{\mathrm{III}} \mathrm{Ph}_{3}$ Cor on the currentvoltage curves in the regarded potential range the single metal transition (III $\leftrightarrow$ II) at $E_{1 / 2}=0.16 \mathrm{~V}$ was detected. The observing magnitude of redox potential for the pointed transition is in accordance with the data of cobalt containing corroles. ${ }^{[30]}$ For the metals with variable valence, such as $\mathrm{Mn}, \mathrm{Fe}$, and $\mathrm{Co}$, and also $\mathrm{Cu}$ (III $\leftrightarrow$ II) in the case of $\mathrm{MPh}_{3} \mathrm{Cor}$, the dependence of potentials on the nature of metal coordinated anion or organic base can be observed.

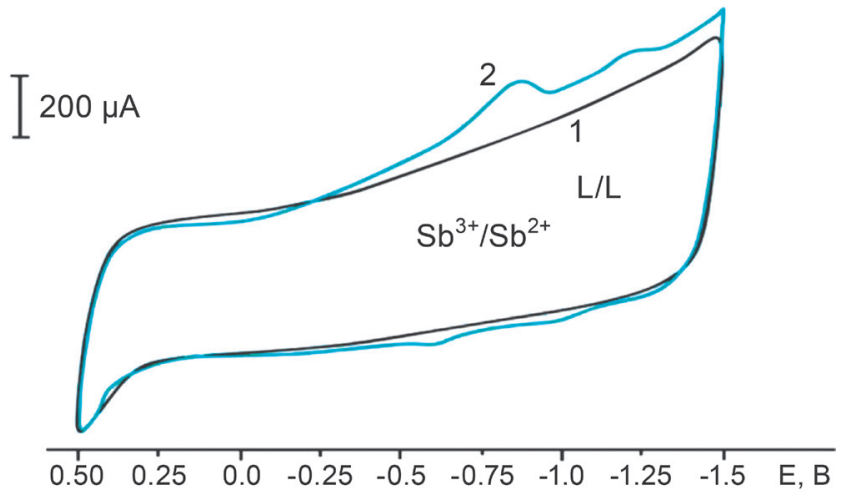

Figure 2. I, $E$-curves for an electrode without a catalyst (1) and with (Py)Sb ${ }^{\mathrm{II}} \mathrm{Ph}_{3} \mathrm{Cor}(2), v=0.02 \mathrm{~V} / \mathrm{s}, \mathrm{Ar}$.

[33] The shift of redox potential for the regarding process in the field of positive magnitude on $50 \mathrm{mV}$ in comparison with previously studied (DMF) $\mathrm{Co}^{\mathrm{III}} \mathrm{Ph}_{3} \mathrm{Cor}^{[30]}$ may be explained by different nature of extra ligands of the cobalt atom. The presence of triphenylphosphine as extraligand in the complex, in this case, provides the process

Table 6. Potentials ( $\left.\mathrm{V}, v_{s} \mathrm{Ag} / \mathrm{AgCl}\right)$ of redox transformations for electrodes with corrole deposition $\left(\mathrm{H}_{3} \mathrm{Ph}_{3} \mathrm{Cor}, \mathrm{H}_{3} \mathrm{Me}_{6} \mathrm{Bu}_{2} \mathrm{Cor}\right)$ or their metal complexes at $v=0.02 \mathrm{~V} / \mathrm{s}$.

\begin{tabular}{|c|c|c|c|c|c|c|}
\hline \multirow{2}{*}{ Compounds } & \multicolumn{3}{|c|}{ Process I $\left(\mathrm{M}^{3+} \leftrightarrow \mathrm{M}^{2+}\right)$} & \multicolumn{3}{|c|}{ Process II $\left(\mathrm{L} \leftrightarrow \mathrm{L}^{-}\right)$} \\
\hline & $E_{\text {cat }}^{\mathrm{I}}$ & $E_{\text {an }}^{\mathrm{I}}$ & $E_{1 / 2}^{\mathrm{I}}$ & $E_{\text {cat }}^{\mathrm{II}}$ & $E_{\text {an }}^{\mathrm{II}}$ & $E_{1 / 2}^{\mathrm{II}}$ \\
\hline $\mathrm{H}_{3} \mathrm{Ph}_{3} \mathrm{Cor}^{[30]}$ & - & - & - & -1.09 & -0.61 & -0.85 \\
\hline $\mathrm{Cu}^{\mathrm{III}} \mathrm{Ph}_{3} \operatorname{Cor}^{[30]}$ & -0.47 & -0.31 & -0.39 & -1.11 & - & - \\
\hline $\mathrm{Ag}^{\mathrm{III}} \mathrm{Ph}_{3} \mathrm{Cor}$ & -0.50 & -0.66 & -0.58 & -1.10 & -1.01 & -1.06 \\
\hline$(\mathrm{Py}) \mathrm{Sb}^{\amalg I I} \mathrm{Ph}_{3} \mathrm{Cor}$ & -0.86 & -0.62 & -0.74 & -1.23 & -1.05 & -1.14 \\
\hline$\left(\mathrm{PPh}_{3}\right) \mathrm{Co}^{\mathrm{III}} \mathrm{Ph}_{3} \mathrm{Cor}$ & 0.12 & 0.20 & 0.16 & -1.19 & -0.97 & -1.08 \\
\hline$(\mathrm{DMF}) \mathrm{Co}^{\mathrm{III}} \mathrm{Ph}_{3} \mathrm{Cor}^{[30]}$ & 0.17 & 0.24 & 0.21 & -1.11 & -0.60 & -0.97 \\
\hline $\mathrm{H}_{3} \mathrm{Me}_{6} \mathrm{Bu}_{2} \mathrm{Cor}$ & - & - & - & -1.13 & -0.58 & -0.86 \\
\hline $\mathrm{Cu}^{\mathrm{III}} \mathrm{Me}_{6} \mathrm{Bu}_{2} \mathrm{Cor}$ & -0.48 & -0.34 & -0.41 & -1.23 & - & - \\
\hline$(\mathrm{Py}) \mathrm{Sb}^{\mathrm{III}} \mathrm{Me}_{6} \mathrm{Bu}_{2} \mathrm{Cor}$ & -0.86 & -0.60 & -0.73 & -1.19 & - & - \\
\hline
\end{tabular}

$E_{1 / 2}=\left(E_{\text {cat }}+E_{\text {an }}\right) / 2$ 
of electrochemical oxidation of the metal and, finally, leads to the stabilization of the complex, with the $3^{+}$oxidation state of metal ion.

For the number of alkyl substituted corroles $\mathrm{H}_{3} \mathrm{Me}_{6} \mathrm{Bu}_{2} \mathrm{Cor}, \quad \mathrm{Cu}^{\mathrm{III}} \mathrm{Me}_{6} \mathrm{Bu}_{2} \mathrm{Cor}, \quad(\mathrm{Py}) \mathrm{Sb}^{\mathrm{III}} \mathrm{Me}_{6} \mathrm{Bu}_{2} \mathrm{Cor}$ in the argon atmosphere on the CVA curves, the single process of the electroreduction of the macrocycle (Table 6 ) is registered. In the $\mathrm{Cu}^{\mathrm{III}} \mathrm{Me}_{6} \mathrm{Bu}_{2}$ Cor complex, trivalent copper is reduced to $\mathrm{Cu}^{\mathrm{II}}$ at a sufficiently high potential of $E_{1 / 2}=-0.41 \mathrm{~V}$ (Table 6), which has $20 \mathrm{mV}$ shift to the negative region, compared to the process $\left(\mathrm{Cu}(\mathrm{III} \rightarrow \mathrm{II}) E_{1 / 2}=-0.39 \mathrm{~V}\right)$ for meso-substituted $\mathrm{Cu}^{\mathrm{III}} \mathrm{Ph}_{3}$ Cor.

For the complex of (Py)Sb ${ }^{\mathrm{III}} \mathrm{Me}_{6} \mathrm{Bu}_{2}$ Cor in the regarded rage of potentials as also for $\left(\mathrm{Py} \mathrm{Sb}^{\mathrm{III}} \mathrm{Ph}_{3} \mathrm{Cor}\right.$, the metal transition (III $\leftrightarrow$ II) at $E_{1 / 2}=-0.73 \mathrm{~V}$ was found.

The study of the process of electroreduction of molecular oxygen in an alkaline solution on the electrodes modified by corroles has been carried out. The characteristic feature of the $I, E$-curves at the insertion of molecular oxygen into the electrolyte is a significant increase of current in the potential range of $-0.1 \ldots-0.4 \mathrm{~V}$, which is caused by the process of $\mathrm{O}_{2}$ electroreduction (Figure 3). The growth of the electrocatalytic activity leads to a significant depolarization effect, appearing in the shift of the electroreduction of molecular oxygen wave to the field of positive magnitude (Figure 3 ). The changing of $E_{1 / 2}\left(\mathrm{O}_{2}\right)$ magnitude for the studied corroles is in the same sequence, as the current density $\left(j_{\mathrm{p}}\right)$ in small polarizations (for example, at $-0.20 \mathrm{~V}$ ) (Table 7).

The analysis of values of effective electrons quantity $n$ (Table 7), calculated in the first maximum using of the Rendels-Shevchik equation ${ }^{[34]}$ with parameters ${ }^{[35]}$ shows that for all the studied catalysts, magnitude of $n$ lies in the 2.1-3.5 range. This allows us to suppose that the process of the electroreduction of molecular oxygen for the investigated catalysts goes parallel along the second and fourth electronic mechanism through the formation of oxygen-containing intermediates.

The $E_{1 / 2}\left(\mathrm{O}_{2}\right)$ magnitude and other parameters of the process (Table 7) show, that according to the ability of the metals in the studied complexes of corroles to electroreduction of molecular oxygen in an alkaline solution, they can be arranged in the following sequence for $\mathrm{MPh}_{3} \mathrm{Cor}$ : without

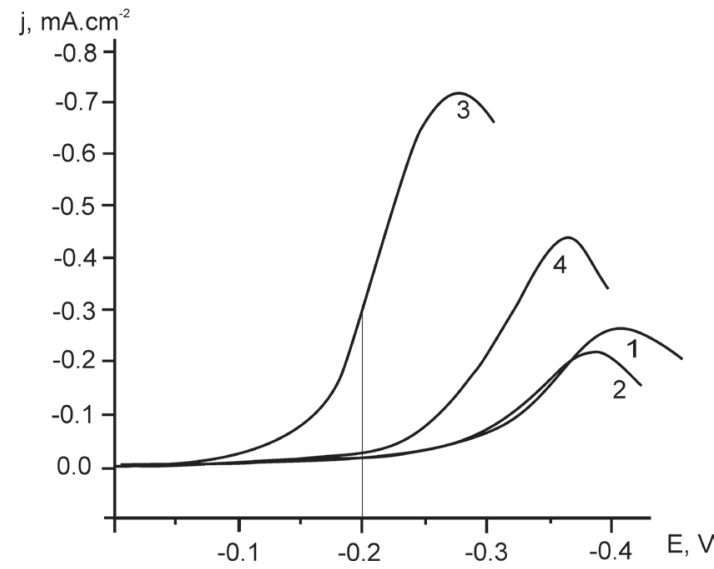

Figure 3. The dependence of the current density of the process of the oxygen electroreduction on the potential of the electrodes: 1 - without a catalyst, $2-\mathrm{Ag}^{\text {III }} \mathrm{Ph}_{3} \mathrm{Cor}, 4-(\mathrm{Py}) \mathrm{Sb}^{\mathrm{II}} \mathrm{Ph}_{3} \mathrm{Cor}, 3$ $\left(\mathrm{PPh}_{3}\right) \mathrm{Co}^{\mathrm{III}} \mathrm{Ph}_{3}$ Cor; $v=0.02 \mathrm{~V} / \mathrm{s}$.

a catalyst $<\mathrm{Ag}^{\mathrm{III}}<\mathrm{Sb}^{\mathrm{III}}<\mathrm{Co}^{\mathrm{III}}$; for the $\mathrm{MMe}_{6} \mathrm{Bu}_{2} \mathrm{Cor}$ : without a catalyst $<\mathrm{H}_{3}<\mathrm{Cu}^{\mathrm{III}}<\mathrm{Sb}^{\mathrm{III}}$.

The entering of $\beta$-alkyl substituents into the corrole molecule, compared with tri-meso-phenylcorroles on the example of coordination compounds of antimony, has a positive effect on electrocatalysis of the reaction of oxygen reduction. In turn, extracoordination on a cobalt atom $\left(\mathrm{L}=\mathrm{PPh}_{3}\right)$ in the composition $\left(\mathrm{PPh}_{3}\right) \mathrm{Co}^{\mathrm{III}} \mathrm{Ph}_{3}$ Cor also leads to a noticeable improvement in the electrocatalytic properties of the complex (by $40 \mathrm{mV}$ ), compared to (DMF) $\mathrm{Co}^{\mathrm{III}} \mathrm{Ph}_{3} \mathrm{Cor}^{[30]}$

\section{Conclusion}

Thus, in this work, the synthesis of mesoand $\beta$-substituted corroles was carried out, some their metal complexes were obtained, and the electrochemical and photooxidative properties of the synthesized compounds were investigated. It has been determined, that the stability of corroles to photosensitizing destruction is more dependent on functional substitution than on the introduction of a metal

Table 7. Magnitude of half-wave potentials, current density, effective number of electrons for the process of electroreduction of molecular oxygen at $v=0.02 \mathrm{~V} / \mathrm{s}$.

\begin{tabular}{|c|c|c|c|c|}
\hline Compound & $E_{1 / 2}\left(\mathrm{O}_{2}\right), \mathrm{V}$ & $\Delta E_{1 / 2}\left(\mathrm{O}_{2}\right)$ & $\begin{array}{l}j_{\mathrm{p}}, \mathrm{mA} / \mathrm{cm}^{2} \\
\text { at }-0.200 \mathrm{~V}\end{array}$ & $n$ \\
\hline $\mathrm{H}_{3} \mathrm{Ph}_{3} \operatorname{Cor}^{[30]}$ & -0.26 & 0.04 & -0.10 & 2.6 \\
\hline $\mathrm{H}_{3}\left(4-\mathrm{NO}_{2}-\mathrm{Ph}\right)_{3} \mathrm{Cor}^{[30]}$ & -0.26 & 0.04 & - & 2.6 \\
\hline $\mathrm{Ag}^{\mathrm{III}} \mathrm{Ph}_{3} \mathrm{Cor}$ & -0.34 & 0.01 & -0.01 & 2.5 \\
\hline$(\mathrm{Py}) \mathrm{Sb}^{\text {III }} \mathrm{Ph}_{3} \mathrm{Cor}$ & -0.31 & 0.04 & -0.01 & 2.1 \\
\hline$\left(\mathrm{PPh}_{3}\right) \mathrm{Co}^{\text {III }} \mathrm{Ph}_{3}$ Cor & -0.22 & 0.03 & -0.28 & 3.5 \\
\hline$(\mathrm{DMF}) \mathrm{Co}^{\mathrm{III}} \mathrm{Ph}_{3} \mathrm{Cor}^{[30]}$ & -0.21 & 0.09 & -0.69 & 3.5 \\
\hline $\mathrm{H}_{3} \mathrm{Me}_{6} \mathrm{Bu}_{2}$ Cor & -0.34 & 0.01 & -0.01 & 2.8 \\
\hline $\mathrm{Cu}^{\mathrm{III}} \mathrm{Me}_{6} \mathrm{Bu}_{2} \mathrm{Cor}$ & -0.32 & 0.02 & -0.05 & 2.8 \\
\hline$(\mathrm{Py}) \mathrm{Sb}^{\mathrm{II}} \mathrm{Me}_{6} \mathrm{Bu}_{2} \mathrm{Cor}$ & -0.25 & 0.10 & -0.05 & 2.1 \\
\hline without a catalyst & -0.35 & & -0.067 & 2.0 \\
\hline
\end{tabular}


cation, as the free base of triphenylcorrole generally showed greater stability to photooxidative destruction, than the studied $\beta$-alkylcorrole. The study of electrochemical properties, in turn, showed a significant influence of both factors on the electrocatalytic reaction of oxygen reduction.

Acknowledgements. The work was carried out within the framework of State assignment of the Ministry of Education and Science of the Russian Federation N 4.7305.2017/8.9.

\section{References}

1. Paolesse R. In: The Porphyrin Handbook, Vol. 2. New York: Academic Press, 2000, p. 201-232.

2. Berezin D.B., Karimov D.R., Kustov A.V. Corroles and Their Derivatives (Koifman O.I., Ed.). Moscow: LENAND, 2018. 304 р. (in Russ.) [Березин Д.Б., Каримов Д.Р., Кустов А.В. Коррольг и их производные (Койфман О.И., ред.). М.: Ленанд, 2018. 304 с.].

3. Paolesse R., Jaquinod L., Nurco D.J., Mini S., Sagone F., Boschi T., Smith K.M. Chem. Commun. 1999, 14, 1307-1308.

4. Semeykin A.S., Syrbu S.A., Koifman O.I. Brill. The Netherlands 2008, 45-93.

5. Lindsey J.S. In: The Porphyrin Handbook, Vol. 1. New York: Academic Press, 2000, p. 45-118.

6. Paolesse R., Nardis S., Sagone F., Khory R.G. J. Org. Chem. 2001, 66, 550-556.

7. Paolesse R., Marini A., Nardis S., Froiio A., Mandoj F., Nurco D.J., Prodi L., Montalti M., Smith K.M. J. Porphyrins Phthalocyanines 2003, 7, 25-36.

8. Gryko D.T., Koszarna B. Org. Biomol. Chem. 2003, 2, 350-357.

9. Koszarna B., Gryko D.T. J. Org. Chem. 2006, 71, 3707-3717.

10. Johnson A.W., Kay I.T. J. Chem. Soc. 1965, 3, 1620-1629.

11. Dolphin D., Johnson A.W., Leng J., van den Broek P. J. Chem. Soc. (C) 1966, 880-884.

12. Paolesse R., Jaquinod L., Senge M.O., Smith K.M. J. Org. Chem. 1997, 62, 6193-6198.

13. Berezin D.B., Karimov D.R., Semeikin A.S., Berezin B.D. Russ. J. Coord. Chem. 2007, 33(11), 857-864.

14. Aviv-Harel I., Gross Z. Coord. Chem. Rev. 2011, 255, 717-736.

15. Barata J.F.B., Neves M.G.P.M.S., Faustino M.A.F., Tomé A.C., Cavaleiro J.A.S. Chem. Rev. 2017, 117, 3192-3253.

16. Boschi T., Licoccia S., Paolesse R., Tagliatesta P., Tehran M.A.J. Chem. Soc., Dalton Trans. 1990, 2, 463-468.
17. Aijun C., Xiaojun P., Jiangli F., Xiuying Ch., Yunkou W., Binchen G. J. Photochem. Photobiol. A: Chemistry 2007, 186, 85-92.

18. Lyubimova T.V., Syrbu S.A., Semeikin A.S. Macroheterocycles 2016, 9, 59-64.

19. Mikhalitsyna E.A., Tyurin V.S., Nefedov S.E., Syrbu S.A., Semeikin A.S., Koifman O.I., Beletskaya I.P. Eur. J. Inorg. Chem. 2012, 36, 5979-5990.

20. Silverstein R.M., Ryskiewicz E.E., Chaikin S.W. J. Am. Chem. Soc. 1954, 76, 4485-4486.

21. Kolodina E.A., Lubimova T.V., Syrbu S.A., Semeikin A.S. Macroheterocycles 2009, 2, 33-41.

22. Licoccia S., Di Vona M.L., Paolesse R. J. Org. Chem. 1998 63, 3190-3195.

23. Stefanelli M., Mastroianni M., Nardis S., Licoccia S., Fronczek F.R., Smith K.M., Zhu W., Ou Z., Kadish K.M., Paolesse R. Inorg. Chem. 2007, 46, 10791-10799.

24. Berezin B.D., Berezin D.B. Chromophore Systems of Macrocycles and Linear Molecules. Moscow: KRASAND, 2013. 240 р. (in Russ.) [Березин Б.Д., Березин Д.Б. Хромофорные системы макрочиклов и линейных молекул. М.: КРАСАНД, 2013. $240 \mathrm{c}$.].

25. Berezin D.B., Likhonina A.E., Serov I.N., Andrianov V.G. $J$. Gen. Chem. 2017, 87, 788-794.

26. Ding T., Aleman E.A., Modarelli D.A., Ziegler C.J. J. Phys. Chem. A 2005, 109, 7411-7417.

27. Berezin D.B., Karimov D.R., Berezin M.B. J. Phys. Chem. 2013, 87, 615-620.

28. Schöfberger W., Lengwin F., Reith L.M., List M., Knör G. Inorg. Chem. Commun. 2010, 13, 1187-1190.

29. Reigh L.M., Stiftinger M., Monkowius U., Knor G., Schoefberger W. Inorg. Chem. 2008, 47, 11143-11153.

30. Bazanov M.I., Berezina N.M., Karimov D.R., Berezin D.B. Russ. J. Electrochem. 2012, 48, 905-910.

31. Wagnert L., Berg A., Stavitski E., Luobeznova I., Gross Z. Levanon H. J. Porphyrins Phthalocyanines 2007, 11, 645-651.

32. Pomarico G., Fronczek F.R., Nardis S., Smith K.M., Paolesse R. J. Porphyrins Phthalocyanines 2011, 15, 1086-1092.

33. Collman J.P., Kaplun M., Decréau R.A. Dalton Trans. 2006, 4, 554-559.

34. Mayranovskiy V.G. Elecrochemistry of Porphyrins. In: Porphyrins: Spectroscopy, Electrochemistry, Application (Enikolopyan N.S., Ed.), Moscow: Nauka, 1987. 127 p. (in Russ.) [Майрановский В.Г. Электрохимия порфиринов. В кн.: Порфирины: спектроскопия, электрохимия, применение (Ениколопян Н.С., ред.). М.: Наука, 1987. 127 с.].

35. Davis R.E., Horvath G.L., Tobias C.W. Electrochim. Acta 1967, 12, 287. 